REPORTS OF MORPHOLOGY
Official Journal of the Scientific Society of Anatomists,
Histologists, Embryologists and Topographic Anatomists
of Ukraine
journal homepage: https://morphology-journal.com

\title{
Modeling of viral-bacterial infections against antibiotic-induced intestinal dysbiosis
}

\author{
Bobyr V.V. ${ }^{1}$, Stechenko L.O. ${ }^{1}$, Shyrobokov V.P. ${ }^{1}$, Cryvosheyeva O.I. ${ }^{1}$, Nazarchuk O.A. ${ }^{2}$, Ponyatovskyi V.A. ${ }^{1}$, \\ Chuhrai S.M. ${ }^{1}$ \\ ${ }^{1}$ Bogomolets National Medical University, Kyiv, Ukraine \\ ${ }^{2}$ National Pirogov Memorial Medical University, Vinnytsya, Ukraine
}

\section{ARTICLE INFO}

Received: 25 February, 2019

Accepted: 27 March, 2019

UDC: $616-022.7: 578 /$

.579]:001.57:616.34-008.87-

008.6:615.33

\section{CORRESPONDING AUTHOR}

e-mail: nazarchukoa@gmail.com

Nazarchuk O.A.
The study of the role of viral-bacterial associations in the etiology of acute intestinal infections is considered new to medical microbiology. The purpose of the study was to determine the effect of viral-bacterial associations on the manifestation of virulence of pathogens and the degree of development of structural-morphological disorders of the internal organs in animals with antibiotic-induced dysbiosis. In a study of 210 white laboratory mice, BALB/c lines formed dysbiosis using antibacterial agents (ampicillin, gentamicin, metronidazole) followed by simulation of the experimental infection. To simulate salmonella infection, mice were infected with a clinical strain of Salmonella typhimurium intraperitoneally. Similarly, the animals were infected with Coxsackie B3 test culture virus (dose $10^{6} T C D_{50}$ ). The sensitivity of mice to Coxsackie $B$ and salmonella viruses was examined for mortality and disease characteristics. The animals were removed from the experiment $24 \mathrm{~h}$ after infection, electronically microscopically studied structural and morphological changes of the internal organs were performed. There was no statistically significant difference in morbidity (23.33-26.66 \%) and mortality (16.66-20.0\%) of mice infected with Coxsackie virus with dysbiotic disorders and preserved microflora. Dysbiotic conditions have been shown to lead to associated viral-bacterial infections in animals and, accordingly, an increase in the incidence of disease and death in experimental animals. Against the background of disturbance of the composition of the normal intestine microbiota in viral bacterial infections, pronounced degenerative changes in the internal organs of animals were established, with signs of generalization. Electrogram data showed the appearance of activation of immunocompetent cells of the body in viral-bacterial infection in animals with impaired intestine microbiocenosis.

Keywods: antimicrobials, bacteria, viruses, dysbiosis, intestinal microbiocenosis, intestinal infections.

\section{Introduction}

Acute intestinal infections (AII) remain one of the world's most pressing health care issues [19]. According to WHO, about 1.7 billion cases of acute diarrhea are reported annually alone in children [1]. Among microorganisms of bacterial nature, the main agents of All are representatives of the family Enterobacteriaceae [14, 15]. Viruses are also important etiologic factors of All in children, especially in early childhood. Viruses are the cause of acute gastroenteritis due to noroviruses, which account for almost a fifth of All; rotaviruses, especially in young children, cause more than 200,000 deaths annually worldwide $[1,6,8]$. Enteroviruses also occupy a significant niche in this respect $[9,13]$.
An important part of the All problem is associated infections due to the impact of microorganisms of different species. In recent years, there has been evidence of an increase in the number of such infections, including virusbacterial infections, especially in the young group. According to scientific literature, it is known that in the conditions of the present virus-associated intestinal infection is recorded in $80-90 \%$ of cases [10].

The issue of viral-bacterial associations is not new to medical microbiology. Back in the middle of the last century, Academician G. Burgwitz proved the ability of yeast cells under the influence of the virus to change their morphological and physiological properties [16]. Interesting 
and valuable, especially for practical medicine, is the degree of manifestation of virulent properties of pathogens in conditions of mixed infection. The enhancement of the pathogenic effect of one microorganism by another has been repeatedly shown in experiments aimed at determining virulence [18]. It should be noted that some virulent bacterial strains, in contrast to avirulent, on the contrary, can have an inhibitory effect on the reproduction of viruses, although in general, viral-bacterial associations are more often characterized by mutual enhancement of pathogens of both microorganisms [5].

However, if the issue of viral-bacterial associations is generally studied extensively, the idea of modeling the pathogenic impact of such associations on animals with dysbiosis is new. This is extremely important today also because the problem of impaired composition of the intestinal microflora is of particular importance in connection with the growth of chronic diseases of the digestive system, as well as the widespread use of antibiotics. Undoubtedly, the gastrointestinal tract is an environment for one of the most complex microbial ecosystems and further research in this area will open up new opportunities for the treatment of infectious diseases.

The purpose of this work is to investigate the effect of viral-bacterial associations on the manifestation of virulence of pathogens and the degree of development of structural-morphological disorders of the internal organs in animals with antibiotic-induced dysbiosis.

\section{Materials and methods}

The research subjects were white laboratory mice of the $B A L B / c$ line. In total, 210 mice were used in the experiment, which were bred in the vivarium of Bogomolets National Medical University.

Antibacterial drugs were used to form dysbiotic conditions, the daily dose of which for animals was $10 \mathrm{mg}$ for ampicillin and metronidazole, and $2.9 \mathrm{mg}$ for gentamicin [3]. The simulation of experimental infections was started 48 hours after discontinuation of antibacterial agents for dysbiosis formation. Experimental salmonellosis was modeled by infecting mice with a pathogenic strain of Salmonella typhimurium isolated and identified at the Kyiv City Clinical Hospital No. 4 (Clinical Isolate No. 7683). The infection of the animals with bacteria was performed intraperitoneally $(i / p)$ in a volume of $0.5 \mathrm{ml}$ (1 billion microbial bodies) per person. Coxsackie B3 viruses were used as test viruses. Infection of animals by viruses was also performed intraperitoneally at a dose of $10^{6} \mathrm{TCD}_{50}$ per animal.

All experimental animals were divided into 7 groups (30 animals in each group). Group 1 - animals with no dysbiotic disorders infected with Coxsackie B3; group 2 animals with no dysbiotic disorders, infected with salmonella; group 3 - animals with no dysbiotic disorders, infected with Salmonella and Coxsackie B3; group 4 animals with dysbiosis infected with Coxsackie B3; group
5 - animals with dysbiosis infected with salmonella; group 6 - animals with dysbiosis infected with Coxsackie B3 and salmonella; group 7 - intact, control. The observation period for animals was 21 days. The comparative susceptibility of mice to Coxsackie B virus and salmonella was studied in terms of mortality and disease (decreased activity, lethargy, trembling, furiousness, diarrhea). The death of animals when infected with Coxsackie B3 virus was observed for 36 days, and for Salmonella infection for 3-4 days. Removal of some animals from the experiment and study of structural and morphological changes of internal organs were carried out 24 hours after infection.

For electron microscopic examination, small intestine, spleen, and liver pieces of $1 \mathrm{~mm}^{3}$ size were selected. They were first fixed with a buffer solution of glutaraldehyde retainer for $1 \mathrm{~h}$, then, after washing with buffer, was fixed for $1 \mathrm{~h}$ with a buffer solution of $1 \%$ osmium tetroxide. The sections were obtained using glass knives on an ultramicrotome "LKB III" (Sweden) and examined using an electron microscope "PEM-125" (Ukraine). Before microscopy, sections were counterstained with uranyl acetate and lead citrate according to the standard procedure.

According to the results of the study, statistical processing was carried out using the software for statistical data processing Microsoft Excel 2016 and "Statistica 5.5" (owned by the Pirogov National Technical University, licensed number AXXR910A374605FA). Probability analysis was performed by Student's t-test. The difference between the indicators was considered statistically significant when the probability of the null hypothesis was less than $5 \%(p<0.05)$.

\section{Results}

The study found that there was no statistically significant difference in the incidence and mortality of animals in groups of mice with dysbiotic disorders and animals with persistent microflora infected with Coxsackie virus: the mortality of mice in both groups was determined in the range of 16.66$20.0 \%$, and diseases were observed in $23.33 \%$ of cases in animals with preserved microflora and in $26.66 \%$ of cases in animals with dysbiosis (Table 1).

It was proved that in the group of animals with preserved microflora the mortality was $16.66 \%$, and in the group of animals with dysbiosis it increased by $6.66 \%$ and was $23.33 \%$, while the incidence of infection in the group of animals with preserved microflora was $20.0 \%$, and in animals with dysbiosis - $30.0 \%$.

In the group of animals in which virus-bacterial infections were modeled against the background of pronounced antibiotic-induced dysbiosis, there was an increase in the death of animals by $20.0 \%$ and an increase in the incidence of disease by $16.66 \%$, compared with the group of experimental animals with viral-bacterial infections conducted the experiment without the formation of dysbiotic states (see table. 1).

Electron microscopic examination of internal organs 
Table 1. Comparative sensitivity of mice with intestinal dysbiosis to Coxsackie B3 viruses, salmonella and their combinations.

\begin{tabular}{|c|c|c|c|c|c|c|c|c|c|c|c|c|}
\hline \multirow{3}{*}{ Man ifestation } & \multicolumn{6}{|c|}{ Animals with preserved microbiocenosis } & \multicolumn{6}{|c|}{ Animals with dysbiosis } \\
\hline & \multicolumn{2}{|c|}{$\begin{array}{c}\text { coxsacks B3 } \\
\quad(n=30)\end{array}$} & \multicolumn{2}{|c|}{$\begin{array}{l}\text { salmonella } \\
\qquad(\mathrm{n}=30)\end{array}$} & \multicolumn{2}{|c|}{$\begin{array}{c}\text { coxsacks B3 + } \\
\text { salmonella }(n=30)\end{array}$} & \multicolumn{2}{|c|}{$\begin{array}{c}\text { coxsacks B3 } \\
(n=30)\end{array}$} & \multicolumn{2}{|c|}{$\begin{array}{l}\text { salmonella } \\
\qquad(\mathrm{n}=30)\end{array}$} & \multicolumn{2}{|c|}{$\begin{array}{c}\text { coxsacks B3 }+ \\
\text { salmonella }(n=30)\end{array}$} \\
\hline & abs. & $\%$ & abs. & $\%$ & abs. & $\%$ & abs. & $\%$ & abs. & $\%$ & abs. & $\%$ \\
\hline Death & 5 & 16,66 & 5 & 16,66 & 7 & 23,33 & 6 & 20,0 & 7 & 23,33 & 13 & 43,33 \\
\hline Signs of illness & 7 & 23,33 & 6 & 20,0 & 9 & 30,0 & 8 & 26,66 & 9 & 30,0 & 14 & 46,66 \\
\hline No changes & 18 & 60,0 & 19 & 63,33 & 13 & 43,33 & 16 & 53,33 & 14 & 46,66 & 3 & 10,0 \\
\hline
\end{tabular}

Notes: the figures in the table indicate the average frequency of detection of a feature, abs. and \%.

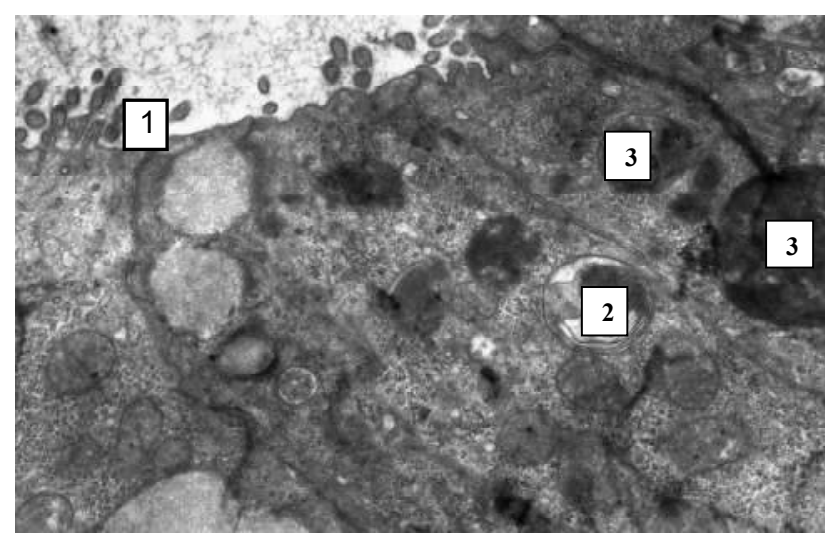

Fig. 1. Electron micrograph. The intestine of mice with dysbiosis after infection with Coxsackie B virus and Salmonella typhimurium. Desquamation of microvilli of epitheliocytes (1), cytoplasm filled by autophagosomes (2) and lysosomes (3). Magnification x19200.

(liver, spleen and small intestine) of animals with preserved microflora infected with Coxsackie B virus (experimental group 1) revealed no pathological changes.

As a result of the study of samples of internal organs (liver,
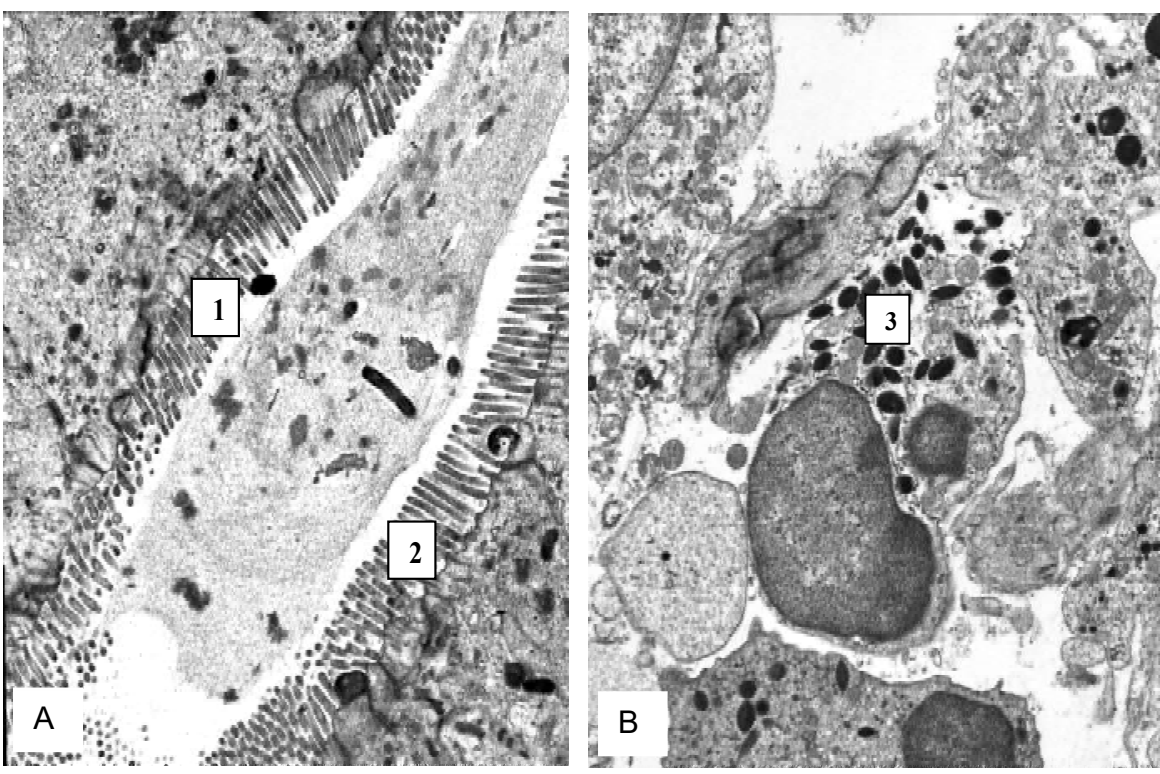

Fig. 3. Electron micrograph. The intestine of mice with dysbiosis after infection with Coxsackie B and Salmonella typhimurium: intestinal lumen (1), epitheliocytes microvilli (2) (A), eosinocytes in the inflammatory zone (3) (B). Magnification x12000 (A), x9600 (B).

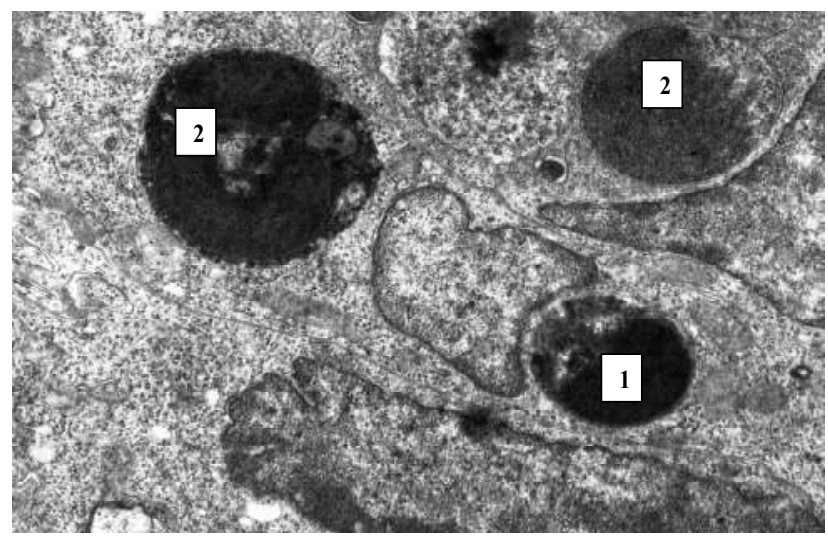

Fig. 2. Electron micrograph. The intestine of mice with dysbiosis after infection with Coxsackie B and Salmonella typhimurium: lymphocyte (1), reticular cells with apoptotic bodies (2). Magnification x12000.

spleen and small intestine) in the intestines of laboratory animals with dysbiosis after viral-bacterial infection, marked structural changes were recorded, which were manifested by total desquamation of microvilli, plasma membrane smoothness, mitochondrial swelling and autophagosome formation (Fig. 1).

In some enterocytes, signs of development of pronounced apoptotic changes were observed, which were accompanied by compaction of cytoplasm, organelles, and formation of apoptotic bodies, which shifted to the apical membrane and were removed from a number of epithelial cells (Fig. 2).

Microbial cells were detected both in the epithelial lining of the mucous membrane and in the lumen of the intestine surrounded by mucus and cellular detritus (Fig. 3A). Signs of minor disorders in the hemomicrocirculatory bed and dystrophic changes in the mucous membrane and submucosal basis of the intestine were noted. The migration of neutrophils, monocytes 


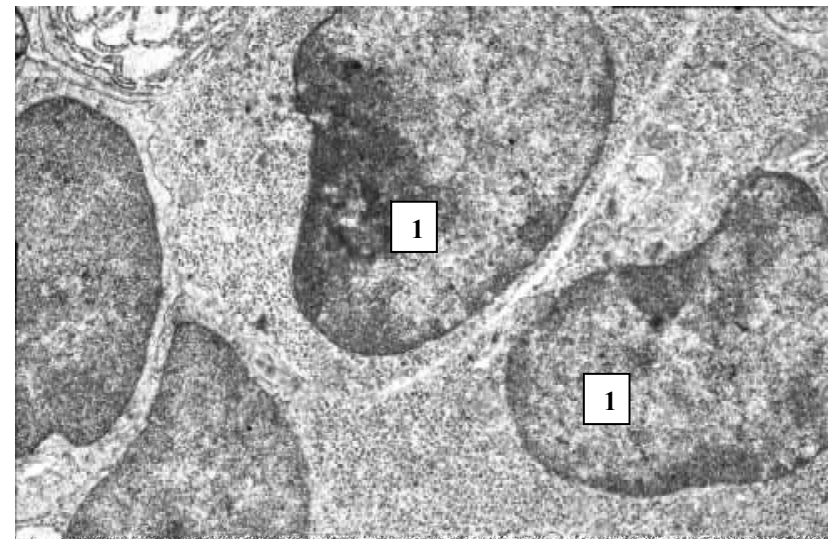

Fig. 4. Electron micrograph. The spleen of mice with dysbiosis after infection with Coxsackie B and Salmonella typhimurium: accumulation of white pulp lymphoblasts (1). Magnification x11200.

and lymphocytes into the intestine interstitium, expansion and swelling of the interstitial space, in which free microbial cells were found (see Fig. 3A, B). Activated macrophages were detected in these sites, in the cytoplasm of which microbial bodies were present with no signs of destruction, which should be considered a phenomenon of endocytobiosis. Dystrophy of superficial epitheliocytes and an increase in the number of neutrophils were also noted. The accumulation of microorganisms in the cytoplasm of epitheliocytes with predominant localization around the nucleus has been determined. In addition, increased infiltration of the mucosa by macrophages was noted.

In animals with dysbiosis, changes in the morphofunctional state of the organs of the immune system were also observed in virus-bacterial infection, in particular in the spleen a decrease in the volume fraction
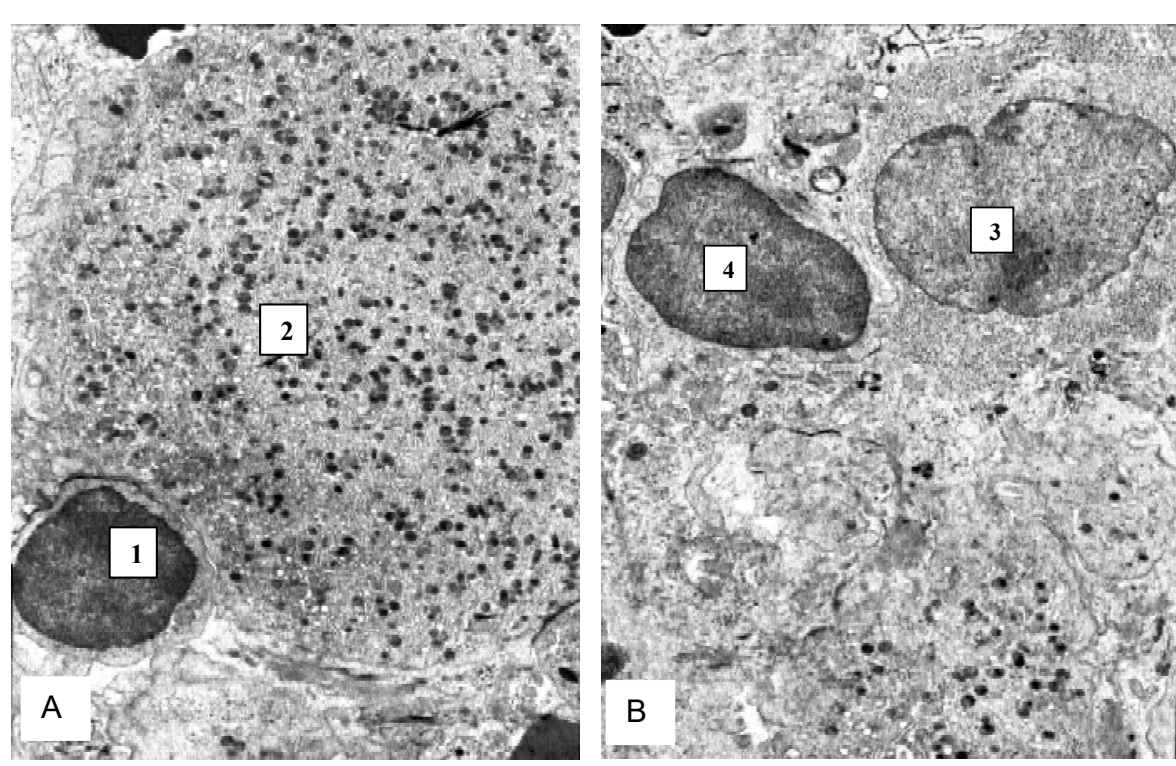

Fig. 6. Electron micrograph. The spleen of mice with dysbiosis after infection with Coxsackie $B$ virus and Salmonella typhimurium. T-lymphocyte (1), giant cell with inclusions in the cytoplasm (2) (A), atrophy of epithelial cells at the periphery of the granuloma surrounded by lymphoblast (3) and macrophage (4) (B). Magnification x7000.

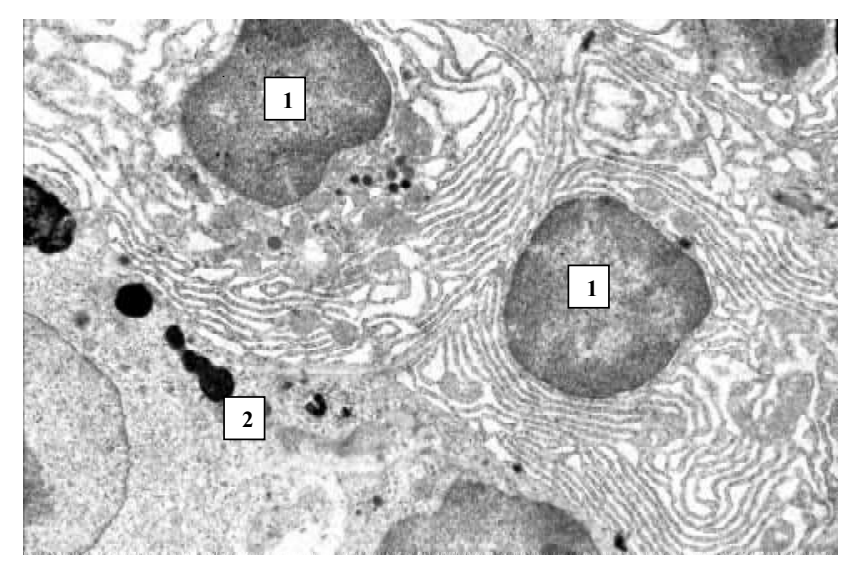

Fig. 5. Electron micrograph. The spleen of mice with dysbiosis after infection with Coxsackie B virus and Salmonella typhimurium. Plasmocytes (1), macrophage fragment (2). Magnification x11200.

of periarterial lymphoid clutches and an increase in the proportion of light centers of lymph nodes (Fig. 4) were detected.

The introduction of salmonella to animals in the spleen tissue revealed ultrastructural signs of an increase in the number of lymphoblasts, plasma cells with enlarged tubules of the granular endoplasmic reticulum (Fig. 5).

Studies of the morphological structure of the spleen under these conditions allowed us to establish the signs of epithelioid cell granuloma formation. The latter were formed by giant, centrally located granuloma hypertrophic and atrophic epithelial cells located along its periphery. Specific inclusions were recorded in the cytoplasm of such cells. It was found that giant cells were usually surrounded by immunocompetent cells (lymphocytes, macrophages, etc.; Fig. 6A, B).

As a result of the introduction of experimental mice Coxsackie virus and salmonella in the liver, necrotic changes in the enlightenment of the nuclei due to the violation of the ratio of eu- and heterochromatin were recorded. The cytoplasm of such cells was characterized by complete or partial cytolysis, dissolution in the main cytosol (Fig. 7A-D).

The death of most organelles was noted. Mitochondria were condensed and partially or completely subject to lysis. The tubules of the granular and agranular endoplasmic reticulum were flattened and destructively changed, and the granular mesh lost ribosomes. These changes were indicative of generalization. Destructive changes of sinusoidal capillaries were also recorded. 


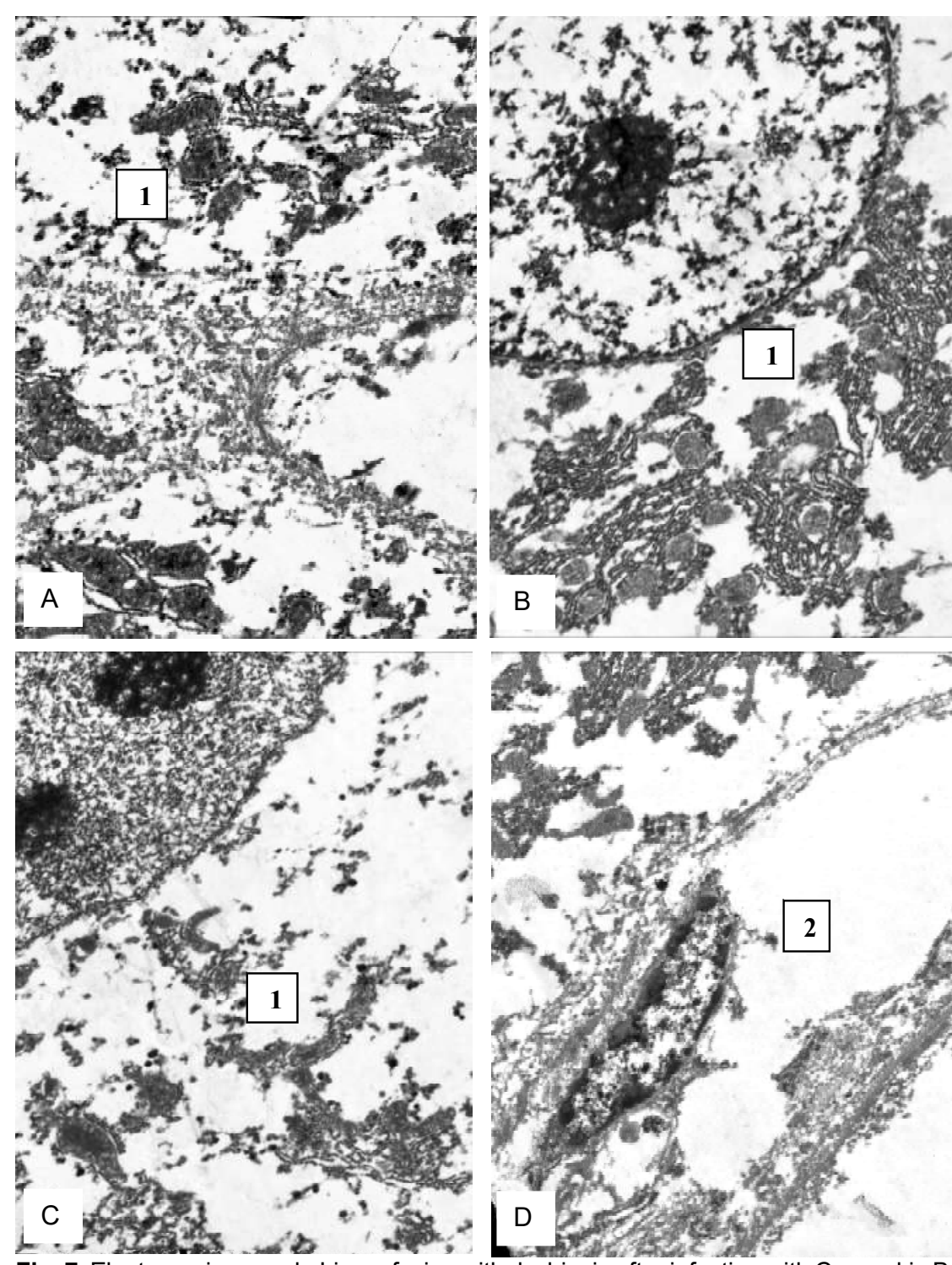

Fig. 7. Electron micrograph. Liver of mice with dysbiosis after infection with Coxsackie $B$ virus and Salmonella typhimurium. Necrotic changes in hepatocytes (1) and sinusoidal capillaries (2). Magnification $\times 12000$.

\section{Discussion}

The use of laboratory animals gives the opportunity to obtain information as close as possible to the human body regarding the features of the pathogenesis of infection, clinical symptoms, immune response or other components of the complex response of the organism to infection. However, modeling of enterovirus infections in animals has certain features that are primarily due to their selective sensitivity to particular types of enteroviruses. Thus, for Coxsackie $B$ viruses effective models are laboratory mice of 1-3 days of age, among polioviruses only 2 serotypes cause clinical symptoms in adult mice, and only with parenteral administration, and to mouse ECOS viruses are not at all sensitive [2, 7, 11, 12]. In general, it should be noted that despite the presence of a certain amount of scientific work on modeling of enterovirus infection in animals, detailed information on the features of the course and factors affecting the infection process is not enough [17].

The choice of the Coxsackie B3 serotype to model infectious processes is due to its proven virulence for mice and clear multiorgan tropism, which allows one to investigate the effect of viral infection on different organs and systems within one block of experiments. In the simulation of experimental salmonellosis, the mortality of animals in the experiments was slightly lower compared to the data of other scientists who noted the animal's death at about $50 \%$ [4].

However, on the basis of a comparative analysis of the ultrastructure of the liver, spleen and small intestine, the appearance of pronounced changes in the internal organs under conditions of viralbacterial infection was established, which gave reason to believe that the dysbiotic disorders significantly exacerbate this process. In particular, they cause disorders of the morphofunctional state of the organs of the immune system, in particular the spleen.

Apparently, the introduction of salmonella to mice leads to activation of immunocompetent cells of the spleen, which is manifested by an increase in the number of detected lymphoblasts, plasma cells with enlarged tubules of the granular endoplasmic reticulum, where gammaglobes are known to be produced.

Our findings indicate that viral bacterial infection often leads to the formation of epithelioid cell granuloma in the spleen. As is known, such granulomas are giant cells, consisting of hypertrophic, located in the center of the granuloma, and atrophic at its periphery epithelial cells. In the cytoplasm of such cells there are specific inclusions, as a rule, giant cells are surrounded by lymphocytes, macrophages or other immunocompetent cells.

According to the data obtained in the study, it was proved that the infection of the body with the Coxsackie virus and Salmonella is accompanied by the appearance of significant morphological changes both in the sinusoidal capillaries of the liver and in hepatocytes. The morphological picture is characterized by necrotic changes, which are ultrastructurally accompanied by damage to cell nuclei, cytolysis and death of most organelles. It is common 
knowledge that such changes in the liver may have a focal character, but when modeling these viral-bacterial infections against the background of dysbiotic disorders, we observe their generalization.

\section{Conclusions}

1. Dysbiotic conditions contribute to the development of associated, in particular virus-bacterial infections in animals, which is primarily manifested by an increase in the incidence and increase in the frequency of

\section{References}

[1]Ahmed, S. M., Hall, A. J., Robinson, A. E., Verhoef, L., Premkumar, P., Parashar, U. D., ... Lopman, B. A. (2014). Global prevalence of norovirus in cases of gastroenteritis: a systematic review and meta-analysis. The Lancet infectious diseases, 14(8), 725-730. doi: 10.1016/S1473-3099(14)70767-4

[2] Andes, D. R., \& Lepak, A. J. (2017). In vivo infection models in the pre-clinical pharmacokinetic/pharmacodynamic evaluation of antimicrobial agents. Current opinion in pharmacology, 36, 94-99. doi: 10.1016/j.coph.2017.09.004

[3] Bobyr, V. V., Ponyatovskiy, V. A., Djugikowa, E. M., \& Shyrobokov, V. P. (2015). Modeling of dysbiotic disorders with laborat ory animals. Biomedical and Biosocial Anthropology, 24, 230233.

[4] Chkhenkeli, V. A., Anisimova, A. V., Romanova, E. D., Kalinovich, A. Ye., \& Promtov, M. V. (2014). Experimental assessment of the efficiency of the "Trametin" at experimental salmonellosis of laboratory and agricultural animals. Bulletin of the Eastern Siberian scientific center of the siberian branch of the Russian academy of medical sciences, 6(100), 80-83.

[5] E'ssel', A. E., Panteleeva, L. G., \& Myasnenko, A. M. (1978). Viral bacterial associations. Publishing House Rostovsk. University.

[6] Gorelov, A. V., \& Usenko, D. V. (2008). Rotavirus infection in children. Current Pediatrics, 7(6), 78-84.

[7] Gyssens, I. C. (2019). Animal models for research in human infectious diseases. CMI editorial policy. Clinical microbiology and infection: the official publication of the European Society of Clinical Microbiology and Infectious Diseases, 25(6), 649. https://doi.org/10.1016/j.cmi.2019.04.010

[8] Kim, B. H., Kim, T. H., \& Lee, M. K. (2016). A Clinico-Epidemiological Comparison Study of Pediatric Acute Viral Gastroenteritis at a Tertiary Care Hospital. Annals of Clinical Microbiology, 19(2), 33-38. https://doi.org/10.5145/ACM.2016.19.2.33

[9] Kotloff, K. L. (2017). The burden and etiology of diarrheal illness in developing countries. Pediatric Clinics, 64(4), 799-814.

[10] Kulieva, Z. M. (2015). Characteristcs of mixed intestinal manifestations of the disease. Modeling of viral-bacterial infections against the background of disturbance of the composition of the normal intestinal microflora allows to record the expressed degenerative changes in the internal organs of animals, which are especially pronounced in the liver, often having a generalized character.

2. Based on the analysis of the electrongrams, it was also suggested that viral bacterial infections that develop in animals with impaired intestinal microbiocenosis are accompanied by activation of immunocompetent cells.

infections of early age with emergency conditions. Russian Medical Journal, 21(4), 21-23.

[11] Marsh, E. K., \& May, R. C. (2012). Caenorhabditis elegans, a model organism for investigating immunity. Appl. Environ. Microbiol., 78(7), 2075-2081. doi: 10.1128/AEM.07486-11

[12] Osborne, N., Avey, M. T., Anestidou, L., Ritskes-Hoitinga, M., \& Griffin, G. (2018). Improving animal research reporting standards. EMBO reports, 19(5), e46069. doi: 10.15252/ embr.201846069

[13] Park, J. O., Jeon, J. S., \& Kim, J. K. (2019). Epidemiologic Trends of Diarrhea-causing Virus Infection Analyzed by Multiplex Reverse Transcription PCR in Cheonan, Korea, 20102018. Microbiology and Biotechnology Letters, 47(2), 317322. https://doi.org/10.4014/mbl.1811.11007

[14] Pollok-Waksmalska, W., Snowiaczek, K., \& Wijas, D. (2019). Salmonellosis among children hospitalized in Pediatric Hospital in Bielsko-Biala, Poland, in the years 2014-2015. Medycyna doswiadczalna i mikrobiologia, 71, 5-12. doi: 10.32394/ $\mathrm{mdm} .71 .01$

[15] Rhoades, N., Barr, T., Hendrickson, S., Prongay, K., Haertel, A., Gill, L., ... \& Messaoudi, I. (2019). Maturation of the infant rhesus macaque gut microbiome and its role in the development of diarrheal disease. Genome biology, 20(1), 1-16. https:// doi.org/10.1186/s13059-019-1789-x

[16] Study of mixed infections in vivo. Retrieved from http:// techpharm.ru/epidemiology $1-120$

[17] Swearengen, J. R. (2018). Choosing the right animal model for infectious disease research. Animal models and experimental medicine, 1(2), 100-108. https://doi.org/10.1002/ame2.12020

[18] Tokar, R. G., Zakstel'skaya, L. Ya., Shendorovich, S. F. (1971). The results of co-infection of tissue culture with influenza virus A2 and Staphylococcus. Journal of microbiology epidemiology immunobiology, 6, 100-103.

[19] World Health Organization (WHO) (2017). Diarrhea [Electronic source]. WHO Bulleting. Retrieved from http://www.who.int/ ru/news-room/fact-sheets/detail/diarrhoeal-disease

\section{МОДЕЛЮВАННЯ ВІРУСНО-БАКТЕРІАЛЬНИХ ІНФЕКЦІЙ НА ТЛІ АНТИБІОТИКОІНДУКОВАНОГО ДИСБІОЗУ КИШКІВНИКА \\ Бобир В.В., Стеченко Л.О., Широбоков В.П., Кривошеєва О.І., Назарчук О.А., Понятовський В.А., Чухрай С.М.}

Вивчення ролі вірусно-бактеріальних асоціацій в етіології гострих кишкових інфекцій вважають новим для медичної мікробіології. Метою дослідження було визначення впливу вірусно-бактеріальних асоціацій на прояв вірулентності збудників та ступінь розвитку структурно-морфологічних порушень внутрішніх органів у тварин з антибіотикоіндукованим дисбіозом. У дослідженні на 210 білих лабораторних мишах лінії BALB/c фрормували дисбіоз з використанням антибактеріальних препаратів (ампіцилін, гентаміцин, метронідазол) з подальшим (через 48 год) моделюванням експериментальної інфрекції. Для моделювання інфрекції сальмонельозу мишей інфрікували клінічним итамом Salmonella typhimurium внутрішньоочеревинно. Аналогічно виконували інфрікування тварин тест-культурою віруса Коксакі В3 (доза 106 ТЦД50). Вивчали чутливість мишей до вірусів Коксакі В та сальмонел за показниками смертності та наявністю ознак захворювання. Виводили тварин із досліду через 24 год після інфрікування, електронно-мікроскопічно вивчали структурно-морфологічні зміни внутрішніх органів. Встановлено відсутність статистично значущої різниці захворюваності (23,33-26,66 \%) та смертності (16,66-20,0 \%) мишей, інфрікованих вірусом Коксакі, з дисбіотичними розладами та зі збереженою мікрофлорою. Доведено, що дисбіотичні 
стани призводили до асоційованих вірусно-бактеріальних інфекцій у тварин, та, відповідно, зростання частоти проявів хвороби та загибелі експериментальних тварин. На фоні порушення складу нормальної мікрофрлори кишківника при віруснобактеріальних інфекціях встановили виражені дегенеративні зміни у внутрішніх органах тварин з ознаками генералізації. Дані електронограм засвідчили появу ознак активації імунокомпетентних клітин в організмі при вірусно-бактеріальній інфекції у тварин з порушеним мікробіоценозом кишківника.

Ключові слова: антимікробні препарати, бактерії, віруси, дисбіоз, мікробіоценоз кишківника, кишкові інфекції.

\section{МОДЕЛИРОВАНИЕ ВИРУСНО-БАКТЕРИАЛЬНЫХ ИНФЕКЦИЙ НА ФОНЕ АНТИБИОТИКОИНДУЦИРОВАННОГО ДИСБИОЗА КИШЕЧНИКА}

Бобыр В.В., Стеченко Л.А., Широбоков В.П., Кривошеева О.И., Назарчук А.А., Понятовский В.А., Чухрай С.М.

Изучение роли вирусно-бактериальных ассоциаций в этиологии острых кишечных инфекций считают новым для медицинской микробиологии. Целью исследования было определение влияния вирусно-бактериальных ассоциаций на проявление вирулентности возбудителей и степень развития структурно-морфологических нарушений внутренних органов уживотных с антибиотикоиндуцированным дисбиозом. В исследовании на 210 белых лабораторных мышах линии BALB/c формировали дисбиоз с использованием антибактериальных препаратов (ампициллин, гентамицин, метронидазол) с последующим (через 48 ч) моделированием экспериментальной инфрекции. Для моделирования инфрекции сальмонеллеза мышей инфицировали клиническим итаммом Salmonella typhimurium внутрибрюшинно. Аналогично выполняли инфрицирование животных тест-культурой вируса Коксаки В3 (доза составила 106 ТЦД50). Изучали чувствительность мышей к вирусам Коксаки В и сальмонелл по показателям смертности и наличию признаков заболевания. Выводили животных из опыта через 24 ч после инфицирования, электронно-микроскопически изучали структурно-морфологические изменения внутренних органов. Установлено отсутствие статистически значимой разницы заболеваемости (23,33-26,66 \%) и смертности (16,66-20,0 \%) мышей, инфрицированных вирусом Коксаки, с дисбиотическими расстройствами и с сохраненной микрофрлорой. Доказано, что дисбиотические состояния приводили к ассоциированным вирусно-бактериальным инфекциям у животных, и, соответственно, росту частоты проявлений болезни и гибели экспериментальных животных. На фоне нарушения состава нормальной микрофрлоры кишечника при вирусно-бактериальных инфекциях установлены выраженные дегенеративные изменения во внутренних органах животных с признаками генерализации. Данные электронограмм показали появление признаков активации иммунокомпетентных клеток в организме при вирусно-бактериальной инсрекции у животных с нарушенным микробиоценозом кишечника.

Ключевые слова: антимикробные препараты, бактерии, вирусы, дисбиоз, микробиоценоз кишечника, кишечные инсрекции. 